\title{
EDITORIAL
}

\section{Imaginários em movimento na cultura e na vida social}

RuMoRes, revista científica on-line dedicada aos estudos de comunicação, linguagem e mídias, concentra-se, em sua vigésima segunda edição, nas abordagens teóricas em torno da noção de imaginário, relacionando-as a objetos privilegiados e correntes no campo do audiovisual. Os artigos reforçam, dessa forma, a concretude, relevância e presença do imaginário na cultura e na vida social, inclusive conectando esses âmbitos indistintamente. No dossiê "De onde vem o imaginário dos filmes e séries de sucesso?", organizado por Sílvio Anaz, nove densos trabalhos de pesquisadores brasileiros e estrangeiros estudam filmes e séries que tiveram reconhecida circulação e sucesso midiático, variando desde Match point, Outlander, Once upon a time e A feiticeira, aos filmes ...E o vento levou, Avatar, Titanic, e aos nacionais Mulheres apaixonadas e Sessão de terapia. Outros artigos, ao trazerem abordagens específicas, tratam sobre arquétipos, sobre a rotinização dos thrillers de conspiração contemporâneos e sobre processos criativos nos estúdios de Hollywood.

Os artigos apresentados no corpo da edição deslocam-se das experiências das produções audiovisuais para tratarem dos efeitos da atuação social fundada em imaginários, especialmente considerando materiais de cunho jornalístico e factual. Em "A colonização da cultura: ainda sobre classificação indicativa", Mayra Rodrigues Gomes investiga variadas estratégias normativas, especialmente a classificação indicativa de filmes e programas televisivos, implicadas no fluxo 
de produtos culturais. Cláudio Novaes, por sua vez, em "Os Golpes de 1964 e 2016: poder, espetáculo, simulacro" entende a produção dos golpes de 1964 e 2016 como espetáculo, usando os conceitos de poder espetacular, de Guy Debord, e a visão de Baudrillard a respeito do processo comunicacional de simulação e de produção de simulacros.

As relações entre política e mídia também são abordadas em "Temer na EBC: uma análise da cobertura da rede pública brasileira dos 111 dias de governo interino", por Franco Iacomini, Tarcis Prado Junior, Moisés Cardoso, Rodrigo Asturian, Leticia Mueller, buscando contribuir para uma compreensão do comportamento da mídia pública brasileira no processo que levou ao impeachment de Dilma Rousseff.

A sociedade do espetáculo é revisitada não somente através das dinâmicas da política, mas também em experiências de intervenção e reapropriações artísticas como "Bottle rack: a ausência da Coca-Cola nas obras de Marcel Duchamp", de Miriam Cristina Carlos Silva e Paulo Celso da Silva, atentos à expansão de suas cargas simbólicas. Numa investigação sobre se o surgimento de novos meios de produção e canais de distribuição possibilita a democratização midiática, Juliana Doretto estuda o jornalismo infantojuvenil em "'Sou fã da revistinha'": as mensagens enviadas pelas crianças ao jornalismo infantojuvenil", analisando as correspondências recebidas pela revista Ciência Hoje das Crianças, de julho de 2013 a junho de 2014 .

O jornalismo é mais uma vez lugar de disputa em "O lead nos títulos jornalísticos: um estudo comparado entre os jornais Folha de S. Paulo e Estado de S. Paulo", de Lucas Santiago Arraes Reino e Thaísa Cristina Bueno, estudando a história do chamado título informativo no meio impresso e no meio digital. A edição se completa, ainda, com a resenha de Ivan Paganotti, "Privilégios, vigilância e planejamento: a luta pelos sentidos na ação da censura", entrando no debate sobre o que seria essa instituição que bloqueia expressões públicas a partir do mais recente livro de Robert Darnton, Censores em ação: como os Estados influenciaram a literatura. 
Esperamos que os artigos reunidos possam motivar novos debates nos campos do entretenimento e do jornalismo, construindo espaços de interlocução e dinamizando as reflexões sobre produções midiáticas e seus efeitos na atuação social. Boas leituras!

Rosana Soares

Andrea Limberto

novembro 2017 